\title{
Two new species of the genus Thinodromus Kraatz, 1857 from the Islands of Borneo and Sulawesi (Coleoptera: Staphylinidae: Oxytelinae)
}

\section{Ава новых вида рода Thinodromus Kraatz, 1857 с островов Борнео и Сумавеси (Coleoptera: Staphylinidae: Oxytelinae)}

\author{
M.Yu. Gildenkov \\ М.Ю. Гицьденков
}

Smolensk State University, Przhevalsky str. 4, Smolensk 214000, Russia. E-mail: mgildenkov@mail.ru Смоленский государственный университет, Пржевальского 4, Смоленск 214000, Россия

KEY WORDS: Coleoptera, Staphylinidae, Thinodromus, new species, Oriental region, Malaysia, Indonesia, Borneo, Sulawesi.

КЛЮЧЕВЫЕ СЛОВА: Coleoptera, Staphylinidae, Thinodromus, новые виды, Восточная биогеографическая область, Малайзия, Индонезия, Борнео, Сулавеси.

ABSTRACT: Two new species of the genus Thinodromus are described: Thinodromus (s.str.) kelabitensis, sp.n. from Borneo (Malaysia) and Thinodromus (s.str.) mamasensis, sp.n. from the Sulawesi.

РЕЗЮМЕ: Описываются два новых вида рода Thinodromus: Thinodromus (s.str.) kelabitensis, sp.n. c Борнео (Малайзия) и Thinodromus (s.str.) mamasensis, sp.n. с Сулвавеси.

The article is a continuation of the author's work on the study of the fauna of the genus Thinodromus Kraatz, 1857 of the Oriental biogeographic region [Gildenkov, 2017, 2018a, b, 2019a, b, 2020]. Two species described in this work do not belong to the «lunatus» group or other known species group of Thinodromus. They are most similar to Thinodromus (s.str.) shavrini Gildenkov, 2020, described from the Philippines.

This paper is based on the specimens deposited in the following collections: $\mathrm{cMG}$ - private collection of M. Gildenkov (Smolensk, Russia); NHMW - Naturhistorisches Museum Wien (Austria). SMNS - Staatliches Museum für Naturkunde in Stuttgart (Germany). In the present study, standard methods were used for the taxonomic research of insects; the preparations were made on an MBS-10 binocular microscope. The genital preparations were processed using $10 \% \mathrm{KOH}$ and then fixed in euparal. In the descriptions and diagnoses giving the length to width ratio for the head, pronotum, and elytra, the following standard units were used: 7 standard units $=0.1 \mathrm{~mm}$; thus, 1 standard unit constitutes about $0.0143 \mathrm{~mm}$. Photographs were taken with a
Canon EOS 5D Mark III camera and a Canon MP-E 65 $\mathrm{mm}$ objective using the extended focus technology.

Thinodromus (s.str.) kelabitensis Gildenkov, sp.n. Figs 1-3.

MATERIAL. Holotype, $0^{7}$, Malaysia, state Sarawak: with labels "MAL., Sarawak 1993 Kelabit HL, 5 km E Bario Pa Ukat, 27.2., 1000m, leg. M. Jäch (16)" (NHMW). Paratype: $10^{7}$ "MAL., Sarawak 1993 Kelabit HL. Bareo Pa Ukat, 27.2., 1000m, leg. H. Zettel (12)" (cMG).

DESCRIPTION (holotype). Length $3.9 \mathrm{~mm}$. Colouration dark brown; legs, 1-8th segments of antennae brownish; The 9-11th segments of the antennae are yellow-brown. Integument is quite shiny, body with fairly long light-coloured seta.

Head transverse, with a wide base, ratio of its length (from posterior margin of head to anterior margin of clypeus) to maximum width is about 25:41. Neck constriction is well expressed. Eyes large, convex, occupying almost entire lateral side of head; temples almost indistinct, the head has the largest width in the eye area (Fig. 1). Head surface with clearly, rather finely and dense punctation. Diameter of punctures is slightly smaller than the eye facet. Distances between punctures slightly smaller than their diameter, interspaces smooth, shiny (Fig. 1). Antennae long, with lengths of all antennal segments noticeably or significantly longer than their width (Fig. 1).

Pronotum heart-shaped, reaches its greatest width after about $2 / 3$ of the length measured from the base, then narrowed (Fig. 1). Ratio of pronotum length to its maximum width is about 39:47. Surface of pronotum with clearly, rather finely and dense punctation. Diameter of punctures is slightly smaller than the eye facet. Distances between punctures slightly smaller than their diameter, interspaces smooth, shiny (Fig. 1). Base of pronotal disc with distinct horseshoeshaped depression (Fig. 1); central part of disc with 2 symmetrical distinct oval depressions.

How to cite this article: Gildenkov M.Yu. 2021. Two new species of the genus Thinodromus Kraatz, 1857 from the Islands of Borneo and Sulawesi (Coleoptera: Staphylinidae: Oxytelinae) // Russian Entomol. J. Vol.30. No.1. P.43-46. doi: 10.15298/rusentj.30.1.06 

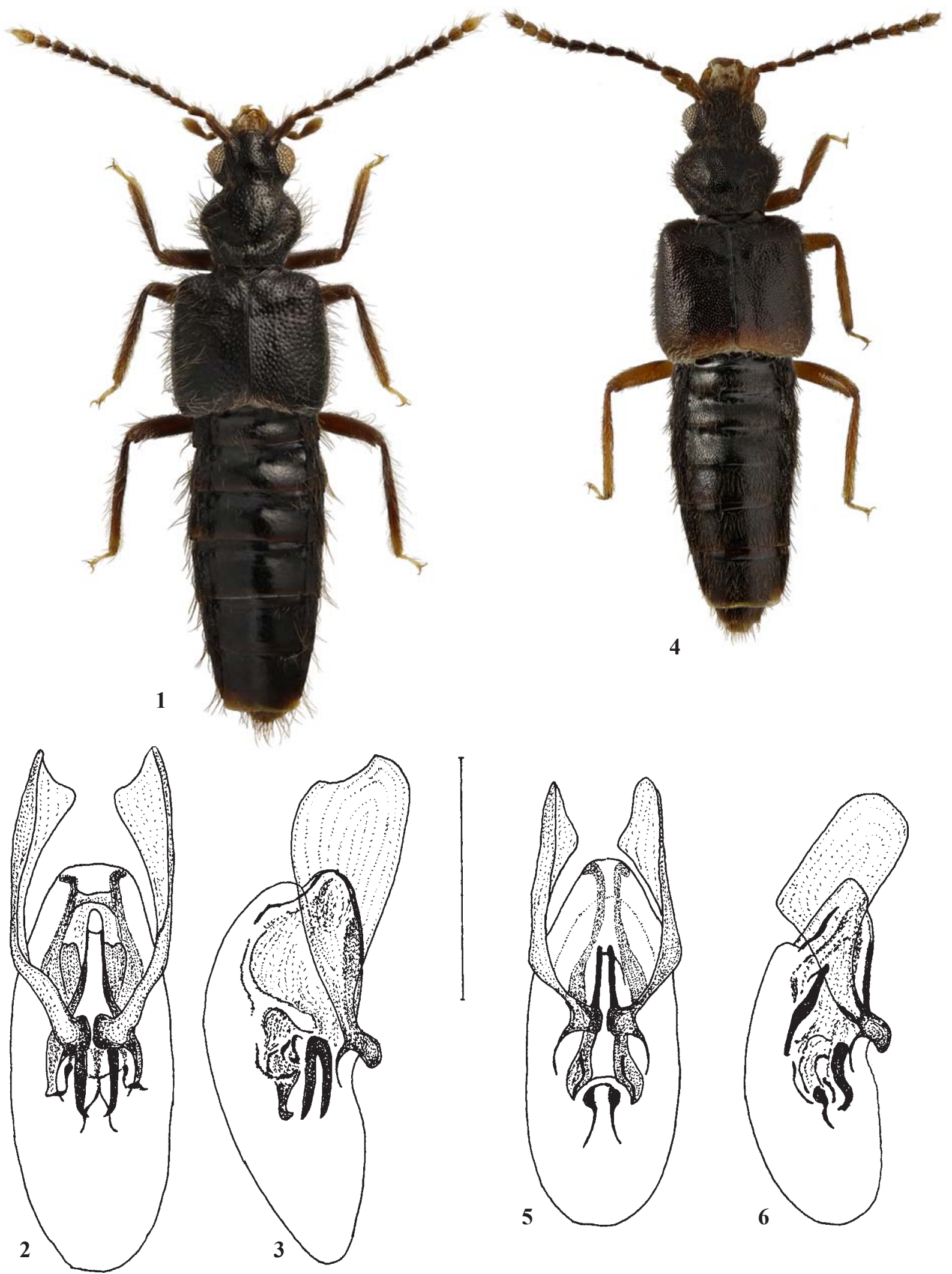

Figs 1-6. Thinodromus spp., holotypes, males: 1-3 - Thinodromus (s.str.) kelabitensis, sp.n.; 4-6 - Thinodromus (s.str.) mamasensis, sp.n.; 1, 4- habitus, dorsal view; 2-3, 5-6 - aedeagus; 2, 5- ventral view; 3, 6 - lateral view. Scale bar: $0.25 \mathrm{~mm}$.

Pис. 1-6. Thinodromus spр., голотипы, самцы: 1-3 - Thinodromus (s.str.) kelabitensis, sp.n.; 4-6 - Thinodromus (s.str.) mamasensis, sp.n.; 1, 4 - внешний вид, сверху; 2-3, 5-6- эдеагус; 2, 5 - снизу; 3, 6- сбоку. Масштаб: 0,25 мм. 
Ratio of length of elytra to their combined width is about 66:69. Elytra with clearly, rather finely and dense punctation. Diameter of punctures is slightly more than the diameter of an eye facet. Distances between punctures slightly smaller than their diameter, interspaces smooth, shiny (Fig. 1).

Abdomen with fine and sparse punctation, shiny.

Aedeagus of a characteristic structure (Figs 2-3).

Female. Unknown.

REMARKS. The species is similar and, apparently, close to Thinodromus (s.str.) shavrini Gildenkov, 2020 [Gildenkov, 2020], described from the Philippines. It is distinguished by a noticeably larger and sparser punctation of the head, pronotum, and elytra, more shiny integument, and a much sparser punctation of the abdomen. Reliably distinguished by the structure of the aedeagus (Figs $2-3$ vs Gildenkov, 2020: Figs 10, 11).

DISTRIBUTION. Borneo (Fig. 7).

ETYMOLOGY. The species is named for its geographical distribution.

\section{Thinodromus (s.str.) mamasensis Gildenkov, sp.n.} Figs 4-6.

MATERIAL. Holotype, $\sigma^{7}$, Indonesia, Sulawesi, Mamasa County: with labels "S Sulawesi, $8 \mathrm{~km}$ W Mamasa, $950 \mathrm{~m} \mathrm{119.20.32 \textrm {E }}$ 2.56.13S 18.-21.Jul 1999, Bolm lgt." (SMNS).

DESCRIPTION (holotype). Length $3.5 \mathrm{~mm}$. Colouration dark-brown, legs, 1-3th, 9-11th segments of antennas and apex of elytra brown. Integument is slightly shiny, body with rather short, light-coloured seta.

Head transverse, with a wide base, ratio of its length (from posterior margin of head to anterior margin of clypeus) to maximum width is about 25:39. Neck constriction is well expressed. Eyes large, convex, occupying almost entire lateral side of head; temples almost indistinct, the head has the largest width in the eye area (Fig. 2). Head surface with clearly, finely and dense punctation. Diameter of punctures is about 2.0 times smaller than the eye facet. Distances between punctures much smaller than their diameter, interspaces smooth, slightly shiny (Fig. 2). Antennae long, with lengths of all antennal segments noticeably or significantly longer than their width (Fig. 2).

Pronotum heart-shaped, reaches its greatest width after 2/ 3 its length from base, then narrowed (Fig. 2). Ratio of pronotum length to its maximum width is about $37: 46$. Surface of pronotum with clearly, finely and dense punctation. Diameter of punctures is about 2.0 times smaller than the eye facet. Distances between punctures much smaller than their diameter, interspaces smooth, slightly shiny (Fig. 2). Base of pronotal disc with distinct horseshoe-shaped depression (Fig. 2 ); central part of disc with 2 symmetrical weakly developed oval depressions.

Ratio of length of elytra to their combined width is about 63:69. Elytra with clearly, finely and dense punctation. Diameter of punctures is about 1.5 times smaller than the eye facet. Distances between punctures much smaller than their diameter, interspaces smooth, slightly shiny (Fig. 1).

Abdomen with fine and dense punctation, slightly shiny.

Aedeagus of a characteristic structure (Figû 5-6).

Female. Unknown.

REMARKS. The species is similar to Thinodromus (s.str.) shavrini Gildenkov, 2020 [Gildenkov, 2020] described from the Philippines. It is distinguished by a noticeably smaller and more dense punctation of the head, pronotum, and elytra. Reliably distinguished by the structure of the aedeagus (Figs 5-6 vs Gildenkov, 2020: Figs 10, 11).

DISTRIBUTION. Sulawesi (Fig. 7).

ETYMOLOGY. The species is named for its geographical distribution.

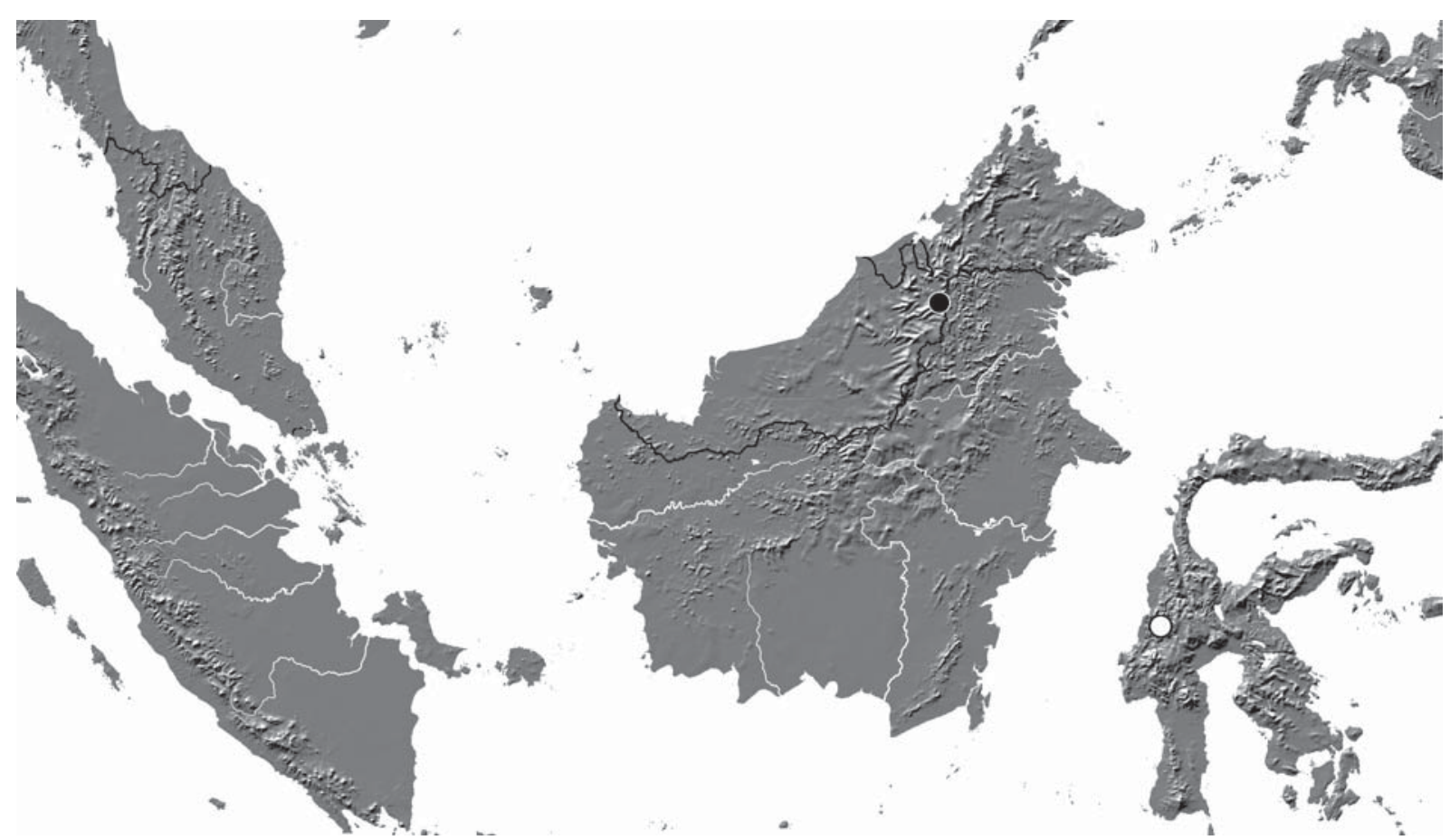

Fig. 7. Distribution of Thinodromus: T. kelabitensis, sp.n. (black circle) in Borneo and T. mamasensis, sp.n. (white circle) in Sulawesi. Рис. 7. Распространение Thinodromus: T. kelabitensis, sp.n. (черный круг) на Борнео и T. mamasensis, sp.n. (белый круг) на Сулавеси. 
Acknowledgements. The author wishes to thank all colleagues for making material available for study: Harald Schillhammer (NHMW) and Wolfgang Schawaller (SMNS). I also thank Kirill Makarov for taking the photos (Moscow State Pedagogical University, Russia) and Alexei Shavrin for the map (Daugavpils University Institute of Systematic Biology, Latvia).

\section{References}

Gildenkov M.Yu. 2017. [A review of the Thinodromus lunatus species-group (Coleoptera, Staphylinidae)] // Zoologicheskii Zhurnal. No.96. No.10. P.1165-1180 [In Russian; English translation: Entomological Review. 2017. Vol.97. No.8. P.1089$1105]$.

Gildenkov M.Yu. 2018a. A new species of the genus Thinodromus Kraatz, 1857 (Coleoptera: Staphylinidae: Oxytelinae) from China // Far Eastern Entomologist. No.356. P.17-20.
Gildenkov M.Yu. 2018b. [Six new species of the genus Thinodromus Kraatz 1857 close to Thinodromus (Amisammus) ripicola (Cameron 1941) (Coleoptera, Staphylinidae, Oxytelinae)] // Zoologicheskii Zhurnal. No.97. No.11. P.1363-1373 [In Russian; English translation: Entomological Review. 2018. Vol.98. No.8. P.1113-1123].

Gildenkov M.Yu. 2019a. New species of the Subgenus Thinodromus Kraatz, 1857 (Coleoptera: Staphylinidae: Oxytelinae), from India and Nepal // Far Eastern Entomologist. No.381. P.15-20.

Gildenkov M.Yu. 2019b. [Three new species of the Thinodromus arcuatus group, genus Thinodromus Kraatz, 1857 (Coleoptera, Staphylinidae, Oxytelinae), from the Oriental region] // Zoologicheskii Zhurnal. No.98. No.11. P.1205-1212 [In Russian; English translation: Entomological Review. 2019. Vol.99. No.8. P.1197-1204].

Gildenkov M.Yu. 2020. Three new species of the genus Thinodromus Kraatz, 1857 from Indonesia and the Philippines (Coleoptera: Staphylinidae: Oxytelinae) // Russian Entomological Journal. Vol.29. No.2. P.148-152. 